\title{
Kartezyen Özne ve Kantçı Öznenin Heidegger’de Anlamı: Dünyasalık
}

\section{Senem ÖNAL ${ }^{1}$}

\section{Özet}

Heidegger'e göre varlık, var-olmakla anlaşılabilendir. Var-olma davranışı ya da var-oluş, insanın bütünsel yapısını ifade eder. $\mathrm{O}$, var olanları kuramsal olarak anlamaktan çok, dünya-ile-birlikte-var oluşunda anlar. Bu yüzden Heidegger insanı, Descartes ve Kant'ın cogito'yla var oluşa getirdiği ayrıma karşı, dünyasallık bağlamında anlar.

Anahtar Sözcükler: Varlık, Descartes, cogito, Kant, Heidegger, dünyasallık.

\section{The meaning of Cartesian and Kantian subject for Heidegger: Worldliness}

\begin{abstract}
To Heidegger, being is understandable with be-ing. The comportment of be-ing or existing means a whole structure of human being. He understands beings as in his being with-in-the-world rather than theoretical understanding. Thus, Heidegger understands human being in the context of worldliness contrary to the difference between cogito and being by Descartes and Kant.
\end{abstract}

Keywords: Being, Descartes, cogito, Kant, Heidegger, worldliness.

\section{Giriş}

Modern felsefe, Descartes'ın öne sürdüğ̈̈ bir ayrımla, zihin-beden düalizmiyle başlamış ve bu ayrımın etkisinde şekillenmiştir. Bu yaklaşım belki de, Ortaçağ'ın yapısından kaynaklanan bir kaçışla, düşünen insanın gücüne sarılmış ve özneye fazlaca bir anlam yüklemenin önünü açmıştır. Aklın doğaya yönelik bilgiyi elde etmedeki başarısı ve onun temelinde bilimlerin gelişme göstermeye başlaması, bilgiyi sağlam bir temele oturtma amacına, dolayısıyla da düşünüyor olmanın kendisine yönelmiştir. Düşünce, kendi kendisinden hareketle kendini, varoluşunu ve dünyayı anlamlandırmaya çalışmıştır.

$\mathrm{Bu}$ anlamda Heidegger'e göre, modern felsefenin yalıtılmış, izole edilmiş öznesi, dış dünyanın gerçekliğini sorgularken, bu kesinliği belirlemeye ilişkin kaynak eksikliğinden dolayı, kendi düşüncelerinin yanılgısına düşer. Kendi benliği üzerine temellendirme çabasıyla, kaynak eksikliğini doğuran bu bakış açısı, kendi içerisinde bir çıkmazdadır ve o modelin yapısı içinde bir çözüme kavuşturulamaz. Kesinliğe ulaşmak için şüpheci bir tutumla yalnızca düşünme yöntemi, kendi bilgisel çıkmazlarında kendine ilişkin doğru bir anlayış geliştiremez. Bu nedenle Heidegger'e göre öncelikle, Kant'ın ve Descartes'in Kartezyen

${ }^{1}$ Akdeniz Üniversitesi Felsefe Bölümü, Antalya Önal, Senem, (2014) "Kartezyen Özne ve Kantçı Öznenin Heidegger'de Anlamı: Dünyasallık", Kilikya Felsefe Dergisi/Cilicia Journal of Philosophy, ss. 63-75 
felsefesinin, özne ve dünyaya yönelik getirdiği ontolojik ön kabulleri aşmak gerekmektedir. Kendi ya da saf ben dışındaki tüm şeyleri nesneleştirme ve bunların gerçekliğini öznelliğe indirgeme yanılgısı, bizim gündelik yaşamımızdaki dünya-içinde ortaya çıkan davranışlarımızı açıklayacak bir bakış açısı sağlamaz. Dolayısıyla modern özne düşüncesini aşmaya yönelik olarak Heidegger, içinde-var-olduğumuzu yadsıyamayacağımız bir dünyada pasif bir izleyici olduğumuzu değil, her zaman aktif bir şekilde katılım içinde olduğumuzu düşünerek başlamamız gerektiğini söyler (Guignon, 1983, s.85).

$\mathrm{Bu}$ anlamda Heidegger, özne-nesne ya da Dasein-Dünya türünden yapılan tüm ayrımların, insanın kendisini, dolayısıyla varlığı anlamasının önünde bir engel olduğunu düşünerek, bu türden ayrımları aşmaya yönelir ve Modern felsefenin özne anlayışına karşı eleştirel bir yaklaşım geliştirir. Bu bağlamda çalışmada öncelikle Descartes ve Kant'ın özne anlayışları, sonra bu anlayış doğrultusunda Heidegger için varoluşun neden dünyasallık bağlamında düşünülemediği gösterilmeye çalışılacaktır.

\section{Descartes’ta Öznenin Ontolojik Olarak Anlaşılması}

Descartes, kaynağından ve kesinliğinden emin olmak istediği bilgi arayışında, dönemin yaygın olan kuşkuculuk anlayışına karşı yöntemsel kuşkuyu kullanarak karşı çıkar. Duyu bilgisinin doğruluğundan, dış dünyanın neliğinden ve matematik doğruların kesinliğinden emin olamayacağımızı öne sürer. Ancak sonunda, şüpheleniyor olduğundan şüphelenemeyeceğini ve şüphe etse bile, bu şüphe ediyor olmanın şüphe eden bir şeyin varlığını gerektirdiği iddiasını, felsefesinin merkezine oturtur. "Düşünüyorum, o halde varım" argümanı da bunu ifade eder. Rasyonel bir sezgiyle elde ettiği kendi düşünen varlığ1, gerçekliğinden tek emin olduğu şeydir (Yalçın, 2010, ss. 19-21). Düşünüyor olmanın gerçekliğini ise Descartes, idesel olarak açıklar:

\footnotetext{
Bir ağaca bakan bir kişi, gerçek bir ağaca bakıp bakmadığından kuşku duyabilir. Bu kişinin ağaç olarak kabul ettiği şey, başka bir fiziksel nesne olabilir ya da bütün bunlar bir düşten ibaret olabilir. Ama Descartes'a göre her durumda bu kişi için bir ağaç ideasının mevcut olduğundan kuşku duyulamaz (Uzun E., Güçlü, Uzun S. ve Yolsal, 2003, s. 712).
}

$\mathrm{Bu}$ anlamda nesnelere ilişkin bilgi, onların ideleri - bir nesneyi temsil etmesinden dolayı sahip olduğu temsili gerçeklik, fikir, düşünce- yoluyla sağlanabilir. Fakat Descartes'a göre, "bir idenin nesnel gerçekliği, o idenin temsil ettiği nesnenin gerçekte var olmasını zorunlu kılmaz" (Yalçın, 2010, ss. 23-25). Kanatlı At idesinin zihnimizde temsili bir gerçekliği olmasına karşın, gerçekte nesnel olarak bir Kanatll At yoktur. Bu anlamda Kanatlı Atın gerçekte bir nesne olarak var olup olamayacağını bilemeyiz, yalnızca onun idesine sahip olabiliriz. Bu nedenle Descartes'a göre gerçeklik, zihnimizin asıl ve dolaysız nesneleri olan idelerdir. Dış gerçekliğe ilişkin bilgimiz, bu idelerle sınırlıdır. Dolayısıyla Descartes'ın bu anlayışı, dış dünyanın varlığı sorununu ortaya çıkarmaktadır. İdeler yoluyla nesnelere ilişkin 
bir bilgimiz olsa da, bu ideler nesnelerin gerçekte var olup olmadıklarını belirleyemeyeceği için dış dünyanın varlığından da emin olamayız (Yalçın, 2010, ss. 23-25).

Descartes için, açık ve seçik bir şekilde apriori olarak bildiği ben bilgisinin elde ediliş tarzı, içe bakıs yöntemi, onu diğer bilgilerden daha kesin ve doğru yapar. Bu anlamda, maddi olanın varlığından emin olamadığı için, benliğin de maddi bir şey olamayacağını belirtir. Ona göre özü düşünme olan benlik, bağımsız bir varoluşa sahip tözdür ve yer kaplama niteliğine sahip olan maddeden farklıdır (Yalçın, 2010, ss. 29-31).

Descartes tözü, Aristoteles'in tanımladığı gibi, varoluşu için kendisinden başka hiçbir şeye dayanmayan şey olarak tanımlar. Ona göre, üç töz vardır: Tanrı, madde ve ruh. Tanrı yaratılmamış, her şeyden bağımsız bir şekilde var olan temel tözdür. Ruh ve madde ise yaratılmış, varoluşları Tanrı'dan başka hiçbir şeye dayanmayan ikincil tözlerdir. Ayrıca Descartes'a göre töz, "algıladığımız her şeyin temelinde bir özne olarak yer alan bir şey” dir. Yani, algıladığımız nesnelerin nitelikleri kendi başlarına değil, bir tözle var olurlar. Dolayısıyla töz ve nitelikleri, gerçekte birbirinden ayrılamaz. Aralarındaki ayrım ise, düşünsel ya da mantıksaldır. Tözün doğasını anlayabilmemizi sağlayan iki temel nitelik, res cogitans (düşünce) ve res extensa (uzam) dır. Res cogitans, düşünen tözün özünü; res extensa ise maddi tözün özünü oluşturur (Yalçın, 2010, ss. 32-33). ${ }^{2}$

Descartes'ın bu ayrımı, kendisi üzerinden yaptığı bir akıl yürütmeyle daha açık kılınabilir. Descartes kendisinde, kendilerine özgü bir takım düşünme yetileri bulduğundan bahseder. İmgeleme ve duyumsama olarak adlandırdığı bu yetiler düşünsel özelliktedir ve Descartes, onlar olmadan da kendisini dolayımsız bir şekilde anlayabildiğini söyler. Fakat tersine, kendi benliği olmadan, yani bu yetilerin kendisine bağlı oldukları bir zihinsel töz olmadan, onları kavrayamayacağını savunur. Çünkü bu yetileri kavrayabilmesi, bir anlayış içerir ve bu da onların kendisinden ayrı olduğunu gösterir. Aynı şekilde, kendisinde gözlemlediği yer değiştirme, farklı duruşlar sergileme gibi yetilerin, ilişkili oldukları bir tözden ayrı olarak var olamayacaklarını ve onsuz anlaşılamayacaklarını söyler. $\mathrm{Bu}$ yer kaplayan yetilerinin bağlı oldukları töz, cisimsel ya da uzamsal bir tözdür. Çünkü kendisindeki bu yetiler, bir uzam kapsar ve uzamsal bir töz sayesinde var olurlar. Bu bakımdan Descartes, cisimsel tözü kendi zihinsel tözünden ayırır ve bu uzam kapsayan yetilerinin kendisinde olamayacağını söyler. Çünkü düşünen kendisinin, duyusal olanın ideasına sahip olarak bu duyusal olanı bilme yetisi olsa da, cisimli şeyler, onun bu anlama etkinliği olmadan da var olabilirler. Dolayısıyla temel niteliği yer kaplama olan uzamsal töz, temel niteliği düşünme olan zihinsel bir tözden zorunlu bir biçimde ayrı olmalıdır (Descartes, 1998, ss. 134-135).

\footnotetext{
${ }^{2}$ Paragrafta bulunan tırnak içerisindeki doğrudan alıntı ve bir önceki referansa kadar olan paragrafın tümü, aynı referans kaynağa aittir. Metnin bütünündeki benzer alıntılar, bu şekilde dikkate alınmalıdır.
} 


\section{Kant ve Aşkınsal Özne}

Kant için gerçekliğin, Descartes’taki düşünüyor oluşun bilincinden oluşmasa da, yargılardan oluştuğu söylenebilir. Ona göre, bilgiyi meydana getiren yalnızca yargılardır. Duyu algısının saf formları olan zaman ve mekân aracılığıyla algılanan izlenimler, anlama yetisinin saf kavramları olan kategoriler aracılığıyla yargılara dönüştürülür. Bu sayede oluşan ve bilgisini elde ettiğimiz şey, görünüşler dünyası (phenomena) ya da evrendir. Bunun dışında nesnel dünyayı, kendinde şey olarak bilmemiz mümkün değildir. Çünkü gerçeklik bize, bizim apriori formlarımız sayesinde açılır. Dış duyunun apriori formu olan mekân (uzam), iç duyunun apriori formu olan zaman ve salt düşünsel kavram olan kategoriler; nesnelerden elde edilen duyumları ilişkilendiren, düzenleyen ve yargılara ulaştırıp, bilinebilir kılan yetilerimizdir. Dolayısıyla böyle bir evreni oluşturan yargılar, ontolojik önceliği de sahiplenir. İnsan zihninin bir ürünü olan yargılar, nesneyi ve kavramı içinde barındırır. Bu anlamda Kant'a göre, nesne ya da kavram, düşünen bir varlık olduğu sürece mümkün olur (Yalçın, 2010, ss. 80-85).

Kant, geleneksel metafizik olarak gördüğü eski ontolojinin, varlık ve doğruluk problemlerine yanıt aradığını ama kendi içinde hiçbir kesinlik taşımadığını savunur. Çünkü ontoloji, varlık hakkında önceden kabul ettiği varsayımlarla işe başlar ve nesnelerin belirlenimlerinin altında yatan şeyi arar. Sistematik, çıkarımsal bir yaklaşımla, nesnelliğe ilişkin evrensel ve zorunlu bilgiyi vermeye çalışır. Nesnel dünyanın kendi başına bir gerçekliği olduğunu ve düşüncenin bu gerçekliği algıladığını savunur. Bu bakımdan sağlam ve güvenilir bir kaynağının olduğunu kabul ettiği dış dünyanın bilgisinin, öznellik alanına bilgi olarak nasıl geçtiğini açıklamaya çalışır. Fakat Kant'a göre bu süreç, diş dünyanın kendi içinde ne olduğu bilinemez kaldığı için ters yönde düşünülmelidir. Bu yüzden, gerçekliğin nesnel olduğu iddiası, nesneler dünyasından elde edilemez. Aksine nesnellik, aklımızın bir sorusudur. Dolayısıyla bu sorunun tam bir yanıtını veremesek bile, onun anlamının bizim zihinsel yarg1 gücümüze bağlı olduğunu bilmemiz gerekir. Gerçekliğin bilgisi, nesneler dünyasından dolayı elde edilen ve bu dünyayı birebir verdiği düşünülen bilgiler evreni değildir. Yani, nesnelerinin varlığının güvenilir kabul edilip, bilgisine sahip olunduğu bir evren yoktur. Tam tersine, nesneler dünyasını ancak kendileri sayesinde bir düzenlilik içinde kavradığımız, koşulsuz ve mutlak olarak aklın ulaştığı yargıları içeren bir düşünme düzeni vardır. Çünkü bu yargılar, ampirik öznelerden ve ampirik zamansal koşullardan bağımsız oluşuyla, nesnelliğin kendisidir. Dolayısıyla nesneler dünyası da ancak bu yargılar sayesinde bilinebilir (Cassirer, 1996, ss. 157-160).

$\mathrm{Bu}$ anlamda Kant'a göre varoluşun, insan zihninin içsel hallerinden ya da biçimlerinden biri olduğu söylenebilir. Çünkü onun için varoluş, bir kategoridir (Yalçın, 2010, s. 101). Zaman1, mekân1, duyu içeriğini (duyum) ve kavramsallaştırıp belirlemeyi insanın zihinsel hallerinde birleştirip, ona bağlı kılan Kant, varoluşu düşüncenin işlevselliğine indirgemiştir. Çünkü akıl ve onun ögeleri, öznel temeller olarak gerçekliği anlayışımızın doğruluk kazanabilmesinin koşuludur. Doğanın bilgisini olanaklı kılan zorunlu koşullar; uzay, 
zaman, büyüklük, sayı, töz ya da ilk neden gibi kavramlar değildir. Aksine bu kavramlara ancak öznellik bir imkân verebilir. Nesnelliğin bilgisini elde edebilen yalnızca aklın evrensel yasalarıdır. Fakat burada, aklın yasalarından ya da aklın düşünme düzeninden, bireysellik anlaşılmamalıdır. Aklın salt yargıları daha çok, nesnel gerçekliğin bilgisini edinmenin öznel olanağıdır (Cassirer, 1996, s. 164).

$\mathrm{Bu}$ açıdan aklın evrensel yargılara ulaşma eğilimi, algılanabilen ve belirlenmiş bir fizikselliği gerektirdiği için, benin kendisine uygulanamamakta ve özne olarak bilgisi de edinilememektedir (Yalçın, 2010, s. 90). Ne ampirik ne de apriori olarak böyle bir şey mümkündür. Çünkü Kant için tüm bilgi, nesnelliğe ilişkin bir algının apriori koşullara uyumunu gerektirir. Bu nedenle benliğin kendisine dönük bilgisi, duyu algısı içeriğine ve aşkınsal form ya da kavramlara tabi olmadığı için edinilemez. Böyle bir şeyin ancak bilincinde olunabilir (Yalçın, 2010, s. 98).

Kant, "nesnelerin değil, tersine genel olarak nesneler hakkında bilgi edinme tarzımızın (bu tarz apriori olarak mümkün olabildiği sürece) bilgisine transendental adını verir" (Cassirer, 1996, s. 163). Ona göre, benliğin algılayan yanı ampirik ben bilincini oluştururken; düşünüm gerçekleştiren yanı, transendental (apriori, saf) ben bilincini oluşturur. Saf ben bilinci, nesnelliğe ilişkin tüm bilginin - apriori veya ampirik- aşkınsal koşuludur. Dolayısıyla o, her türlü deneyimi önceler; bu anlamda zaman ve mekânda yer almaz, aksine onların kaynağıdır (Yalçın, 2010, s. 89).

Ayrıca Kant için benin özüne ulaşılamaması, onun bedenden ayrı, ölümsüz bir töz olduğu anlamına gelmez. Bu noktada Kant, doğada yaptığı fenomenal-numenal ayrımını benlik için de yapar. Zihnin, duyu algılarından elde ettiği kavramlar, fenomenal yani anlaşılabilir ve açıklanabilir niteliktedir. Fakat onun, bir de bu işleyiş haricinde kendi gerçekliği, yani kaynağı zihnin kendisinde olan numenal, bilinemez bir işleyiş vardır (Yalçın, 2010, ss. 90-93). Bu bakımdan, zihindeki kavramları da iki şekilde belirlemiştir: "Birincisi, duyumlardan soyutlama yoluyla elde edilenler, yani kaynağı duyum olanlardır. İkincisi, bu soyutlanmış kavramları ayırmayı, karşılaştırmayı ve ilişkilendirmeyi sağlayan anlık yasalarından elde edilenler, yani kaynağı anlık olan salt anlık kavramlarıdır" (Cassirer, 1996, s. 115).

Heidegger'in, Descartes ve Kant'ın Özne Anlayışlarına Eleştirisi; Dünyasallık Kavramı

Heidegger, Descartes’ta düşünen tözün ve maddi tözün var olmaya kaynaklık edişini ve Kant'ta aşkınsal öznenin apriori formlarında gerçekleşen varoluşun düşünce sistemi içerisinde anlaşılmasını, varoluşa getirilen bir ayrım (var olanlar ve özne) olarak görmektedir. Descartes'la başlayan zihin-beden düalizmi, kendisinden sonra gelecek bütün ayrımlara öncel olmakla birlikte, epistemoloji ve ontoloji ayrımının belirsizleşmesinin de başlangıcı olmuştur. $\mathrm{Bu}$ bakımdan akıl, gerçekliğe bir temel sağlamaya çalışarak, fiziksel olarak var olan her şeyi 
kavramaya, bilmeye yönelmiştir. Ve daha çok fiziksellikle özdeşleşen dünyanın ne olduğuna ilişkin yaklaşımlar geliştirilmeye başlanmıştır.

\section{Heidegger'in, Descartes'ın Töz Anlayışında Gelişen Özne Anlayışına Eleştirisi}

Descartes, düşünme yetisini, bedensel yetiden ayırarak, bu yetilerini kendilerine özgü bir töze yüklemiştir. Düşünme yetisi, anlıksal, düşünsel bir töz olmaksızın var olamamakta; yer kaplama anlamındaki uzam yetisi de cisimsel bir töz olmadan var olamamaktadır. Üstelik bu iki töz, insanda bulunmalarına rağmen bağımsız olarak var olmakta ve birbirlerine erişilemez haldedirler. Çünkü düşünme yetisi, cisimsel olanı yalnızca nitelikleri aracılığıyla bilebilir (Descartes, 1998, s. 135). Uzanım; genişlik, derinlik, uzunluk gibi nitelikleriyle, tüm uzamsal şeylerin, dolayısıyla dünyanın da belirleyenidir. Descartes'a göre bu dünya, yalnızca matematik, geometri gibi bilimler sayesinde, uzamlı şeylere ilişkin duyumların ideleri yoluyla bilinebilir. Bu bakımdan Heidegger'e göre Descartes'ın yaptığı, dünyaya, zaten onun olan nitelikleri geri vermektir. Dünyanın en çok kendisine ait ve ona özgü olan yer kaplama niteliği, bu bilimler aracılığıyla ona tekrar dayatılmaktadır. Bu yüzden "Descartes dünyaya, dünya-içinde-varolanlara ve Dasein'a ontolojik bakımdan erişimi” en başından engellemektedir. Yani uzam, yalnızca uzamsal bir tözün eşlik ettiği bir nitelik olarak kalmaktadır (Heidegger, 2008, s. 93).

Descartes'ta var olanın, tözüyle birlikte var olduğu düşüncesi, Aristoteles'in ousia anlayışının bir yorumudur. Buna göre töz, hem var olanın varlığını hem de var olanın kendisini ifade eder. Yani var olan, her zaman kendisine özgü tözüyle birlikte var olur. Descartes için de düşünen bir var olan, düşünsel bir tözle; uzam kaplayan bir var olan uzamsal, uzamlı bir tözle birlikte var olur. Bu anlamda Heidegger'e göre, tözün tözselliğinin özü, sahip olduğu yüklemleri (nitelikleri) sayesinde anlaş1labilmektedir (Heidegger, 2008, ss. 93-95). Bu anlamda Descartes tözü, hem kendisi olarak hem de ilineklerinde öz olarak bulunuşuyla anlamıştır (Camc1, 2014, s. 21).

Bunun yanı sıra Descartes için, üçüncü bir töz olarak Tanrı vardır. Fakat o, yaratılmamıştır ve dolayısıyla sonsuzdur. Tanrı dışında bütün var olanlar, düşünsel ve maddi tözler de dâhil yaratılmıştır. Descartes için bu üç töz de vardır, yani var olandır. Ancak Heidegger'e göre, sonlu ve sonsuz oluşları bakımından farklılık gösteren bu tözlerin var oluşu, örtük bir şekilde bir soruna işaret etmektedir. Töz, tanımı gereği, "var olabilmek için başka herhangi bir var olana ihtiyaç duymayan," dolayısıyla yaratılmamış olandır. Bu açıdan, hem sonlu hem de sonsuz olana vardır demek, onları var olan olarak görmek demektir. Böyle bir yaklaşım, sonsuzun sonluya indirgenişine ve sonlunun da sonsuz olarak anlaşılmasına neden olmaktadır. Fakat Heidegger için var olmak, yani var-lık kavramı, her zaman aynı olan bir şeyi ya da tek bir şeyi ifade etmez. O, bir isim olmaktan çok anlaşıllır ${ }^{3}$ olandır. Descartes

\footnotetext{
${ }^{3} \mathrm{Bu}$ anlayış, belirsiz, muğlâk olmakla birlikte bir olgu olarak görülmesi gereken bir anlayıştır. "Varlığı bu ortalama, bulanık, örtük anlayışımız da bir olgudur” (Heidegger, 2008, s. 5).
} 
ise, $\operatorname{varl} l k 1_{1}$ bu yönüyle düşünmeksizin, onu belirli yani töz olarak kabul etmiştir. Bu anlamda Heidegger'e göre varlık, belirli bir şey ya da töz değil, kendisini açandır, var-olmakla anlaşılabilendir (Heidegger, 2008, s. 96-99).

Diğer yandan Descartes için zihin ve beden, birbirinden tamamen ayrı iki töz oldukları için birbirinden bağımsız olarak anlaşılabilir ve ontolojik olarak birbirinden bağımsız bir şekilde var olabilirler. Bu nedenle zihin ve beden arasında epistemolojik ve ontolojik bir ayrım vardır (Yalçın, 2010, ss. 34-35). Descartes'ın kesinliğinden emin olduğu düşünen töz, maddeyi doğrudan doğruya bilemez, onun ikincil özellikleri yoluyla dolaylı olarak bilir. Bu şekilde Descartes, varlık yorumunda keskin ayrımlara giderek, bu ayrımları birbirine erişilemez kılmıştır. Heidegger'e göre, düşünce ve madde arasında böyle bir tutum, epistemolojik açmaza ve ontolojik çelişkilere neden olur (Olafson, 1997, ss. 48-49; Akt: Tümkaya, 2010, s. 21). Düşünen özne, dünyayı anlamlandırmaya çalışırken, kendisine ve uzama dayalı bir temele oturtmaya çalışmıştır. Dolayısıyla Kartezyen felsefede düşünce ve maddeye verilen bu tözsellik statüsü, onları gerçekliğin merkezi konumuna getirmiştir (Guignon, 1983, ss. 34-38; Akt: Tümkaya, 2010, s. 21).

Tüm bunlara rağmen Heidegger (2008) için, “Descartes'ın kabul edilebilir tek tespiti, varlı̆̆ıyla diğer bütün var olanları temellendiren, dünya-içindeki-varolanların esası olan maddi doğanın ontolojik karakterizasyonunun temelini atmasıdır” (s. 102). Ama yine de, dünyaya ilişkin maddi bir temelden yola çıkılarak dünyanın dünyasallığı, dünya-içindekivarolanlar ve Dasein anlaşılamaz. Bu bakımdan Heidegger'e göre Descartes, uzamın uzamsallık ya da dünyanın dünyasallık olarak anlaşılabileceğini göz ardı etmiş ve varlığı sürekli mevcut oluş olarak anlamıştır. Dolayısıyla Descartes, uzamsal olanın, uzam niteliğindeki bir temelden ontolojik olarak kendisini açışını kavrayamamıştır. Çünkü o, önceden ben ve dünya ayrımını öne sürmüştür. Ancak Heidegger'e göre bu ayrım temelinde, yalnızca bilme edimiyle var olana yaklaşılabilmekte ve var olanın kendisini kendisi olarak ortaya koyuşu engellenmektedir. $\mathrm{Bu}$ açışa olanak sağlayan ise yalnızca, uzamın uzamsallığında ya da dünyanın dünyasallığında, mesafe kaldırarak, var olanı dolayısıyla varlığı anlayış içinde olan Dasein'ın bir-şey-için yönelimsel davranışıdır (Heidegger, 2008, ss. 104-105).

\section{Heidegger'in, Kant'ın Aşkınsal Özne Anlayışına Eleştirisi}

Kant, cogitonun işlevselliğinin, varlığın bilgisini edinmek için güvenilir ve sağlam bir temel olduğunu ileri sürmüştür. Cogitonun gerçek varoluşu olarak ilişki kuran, bağlayan ve düzenleyen yapısı, copulayı ${ }^{4}$ kullanışıyla ontolojik ve ontik olan arasında asılı kalmaktadır. Yani, nesnelerin duyumlarından elde edilen algıların kavramları, salt aklın kavramlarıyla düzenlenip, anlamlı yargılara, -dır ortacıyla ifade edilen önermelere dönüştürülmektedir. Dış

\footnotetext{
4 "Önermesel mantığın gerçekliği açıklayış şekli olarak, bilincin sonlu şeylerde - $d \imath r$ olarak tanımlama yapması, şeyleri belirlemesidir" (Camc1, 2014, s. 23).
} 
dünya, algının aşkınsal birliğinde anlamlandırılmakta, orada gerçekliğini bulmaktadır. Böylelikle cogito, hem salt aklın işleyişiyle ulaştığı sonuçlarla aşkınsal olmakta hem de nesneleri deneyimleyebilmesinden dolayı sahip olduğu ampirik ben bilinciyle, bu iki ayrım arasında ilişki kuran anlamında uzamda belirsiz bir yer edinmektedir (Camcı, 2014, s. 23).

Kant'a göre zaman ve uzam nesnelliğe değil, transendental özneye aittir ve onun duyu algısının saf formlarından biridir (Yalçın, 2010, s. 115). Bu da Heidegger için, zamanın ve uzamın içsel görünün saf formuna indirgenip, bir temele sahipmiş ve düşünen öznenin dışında bir varlığ1 yokmuş gibi düşünülmesidir. Bu nedenle Kant'ın, gerçekliği zihnin formlarına uygunluğu açısından düşünmesi bir yanılgıdır (Heidegger, 1962, s. 94; Akt: Tümkaya, 2010, s. 20).

Heidegger için geleneksel ontolojinin yaptığ 1 şey, " var olanları tek bir oluş tarzı temelinde açıklamaktır” (Dreyfus, 1997, s. 115; Akt: Tümkaya, 2010, s. 21). Bu anlamda dünya, aşkınsal öznenin ya da düşünen tözün kurucu olanakları sayesinde bize açılır. Bir başka deyişle, "dünyayla ilişkimizin mümkün formu, onunla karşılaşmamızdan önce rasyonel olanaklar çerçevesinde belirlenmiştir" (Heidegger, 2008, s. 96; Akt; Tümkaya, 2010, ss. 2122). Daha önce de belirtildiği gibi, diş dünyaya ilişkin bilgimiz, Descartes için fiziksel nesnelerin ideleri yoluyla sağlanır. Bunun dışında, onların dolayımsız ve gerçek bilgisini edinemeyiz. Kant için de, dış dünyada algıladığımız izlenimler, algımızın formları olan zaman ve mekân aracılığıyla yargısal kategorilere dönüşür. Dünyaya bakışımız bu şekilde önceden belirlenir ve dolayısıyla nesnel gerçekliğin kendi içinde ne olduğunun bilgisi bize saklı kalır. Ancak Heidegger için böyle bir tutumla dünyayı anlamaya çalışmak, onu anlamından soyutlayarak kendisiyle ilgisiz kılmaktır (Dreyfus, 1997, s. 116; Akt: Tümkaya, 2010, s. 22). Bu bakımdan, bize açılan aslında dünya değil, düşünen yanımızın şema $a^{5}$ larıdır.

$\mathrm{Bu}$ anlamda Heidegger için fiziksel nesneler ya da dünyayla birlikte var olan olarak insan, onları oldukları gibi anlamanın önüne engel koymamalı, bu dünyada kendisini onlarla birlikte açışını anlamaya çalışmalıdır. Böylelikle nesnelliğin varlığından şüpheye düşmemize gerek kalmayacak, bütünselliği içinde dünyayı deneyimlememizin ve bu sayede onu anlamamızın yolu açılmış olacaktır.

Bütünsellik kavramının Heidegger için ifade ettiği şey, dünyanın dünyasallı̆̆ıdır. Buna göre, biz dünyayla karşılaşmadan önce o, kendi içinde bir oluşa, ontolojik bir önceliğe ve belirlenmişliğe zaten sahiptir. Fırlatılıp atılmışlı̆̆ımız sayesinde biz, bir şekilde ve her zaman, dünyaya dâhil oluruz, ona yöneliriz, onunla ilişki içinde oluruz. Bu anlamda da dünyanın dünyasallığ1, ona ilişkin bilgimizi öncelemekte olan bütünsellik olur (Dreyfus, 1997, s. 115; Akt: Tümkaya, 2010, ss. 22-23).

\footnotetext{
${ }^{5}$ Transendental şema; duyulardan gelen algılarla anlama yetisinin saf kavramlarını birleştirmeyi sağlayan, zaman formundaki transendental bir belirlenimdir (Yalçın, 2010, s. 84).
} 


\section{Kant'ta Dünya İdesi}

Kant için az önce bahsedilen anlamda, dünyanın dünyasallı̆̆ 1 ya da uzamın uzamsallığ 1 düşünülemez. Çünkü akıl, böyle bir şeyi düşünmeye kalkıştığında totolojik bir tutum sergiler ve antinomiye ("kendi içinde boşu boşuna dönen bir kavram çatışması" (Heimsoeth, 2007, s. 101) olarak diyalektiğe) düşer (Camc1, 2010, s. 796). Bunun nedeni Kant'a göre, insan aklının anlamında ya da ne olarak var olduğunda (işlev gördüğünde) saklıdır. Ampirik olarak deneyimin nesnesi olabilen insan, aynı zamanda bu deneyimin öznesidir de. Düşünen, algılayan, nedensel bağlantılar kuran, yapısında bulunan formlar (zaman-uzam) sayesinde güvenli sonuçlara ulaşarak nesnelliğin bilgisini edinen akıl, bunların yanı sıra kendi-içinde mantıksal işlevlerinden de kaçınamaz. Bunun sonucunda akıl, kendi kavramlarını ya da idelerini, gerçek olma iddiasıyla anlama yetisine dayatır. Fakat Kant için gerçek olmak, apriori sentetik yargılarla ifade edilebilir olmak demektir. Bu nedenle aklın kendi etkinliliğinin, işleyişinin zorunlu bir sonucu olan bu ideleri; geçerliliği olan, kavranan bir şey hakkında bilgi veren ideler olarak kabul edilemez. Bu ideler; ruh, evren ve Tanrı ideleridir. Burada konuyla ilgisi açısından yalnızca evren idesi ele alınacaktır (Cassirer, 1996, s. 134).

Kant'a göre akıl, apriori sentetik yargılara ulaşırken bir nedensellik ilkesinin belirlenimi içerisindedir. Zaman ve mekân formları içindeki her olay, bir öncekinin sonucu ve bir sonrakinin nedenidir. Yalnızca bu neden-sonuç ilişkisi sayesinde kavranabilir şeylerin bilgisi edinilebilir. Ama yine de ak1l, kendi yapısından kaynaklanan bir düşünmeyle, bu neden-sonuç ilişkisinin bütününü, yani koşulsuz ve belirlenmemiş olan evreni kavramak ister. Evren düşüncesi, idesi ise Kant için, aklın bir diyalektiği, yanılsaması ya da oyunu olmaktan öteye geçemez. Çünkü evrenin deneyiminin bilgisine sahip olunabileceği hiçbir durum yoktur. Yani evren, bir nesne olarak zaman-mekân formları içinde algısına sahip olabileceğimiz ve anlama yetimiz aracılığılyla apriori sentetik yargısını elde edebileceğimiz bir nesne değildir. Kant'a göre yanılsama olarak kabul edilemeyecek şey, aklın nesnelerle, onların duyusal kavramlarıyla ve aklın kendi kategorileriyle ulaştığı sonuçlardır. Buna karşılık evren idesi, nesnelerin ya da bilebildiğimiz her şeyin, her koşulun üstünde olan ve hiçbir koşula bağlı olmayan bir tümlüğün olduğu düşüncesidir. Kant için, böyle bir koşulsuz bütünlüğü düşünebiliriz ama onu hiçbir zaman bilemeyiz. Çünkü algısız kavramların gerçekliği yoktur (Heimsoeth, 2007, s. 102-106).

$\mathrm{Bu}$ anlamda Kant, evrenin ya da dünyanın deneyimlenebilirliğinden öte, kendisinin sonlu ya da sonsuz oluşunu bilemeyeceğimizi söyler. Çünkü kavramsal, mutlak tamlık, başlangıcını ve sonunu bilmediğimiz duyulur gerçekliği aşan, zaman ve mekân formlarımızı da aşan bir tamlıktır. Bu nedenle evrenin, dünyanın kendisinin sonlu ya da sonsuz oluşunu savunamayız (Heimsoeth, ss. 106-107). Bunun yanı sıra aklın, bölünebilirlik anlamında evrenin sonlu ya da sonsuz oluşunu belirleme isteği, hem en son bölünemez olana, hem de sonsuz bölünebilirlikte bir sürüp gitmeye ulaştırmaktadır. Tek tek nesnelerin ve bunların 
tümlüğü olarak dünyanın sonsuza dek bölünebileceğini düşünmek, onun sonsuz sayıda uzamsal parça içerdiği anlamına gelmez. Bu yalnızca aklın mantıksal işleyişinin bir ürünü, varlık yapısıdır. Dolayısıyla Kant için, algılanabilir geçekliğin algılayamayacă̆ımız kavramsal tümlügünü yalnızca matematiksel, sayısal olarak düşünebiliriz. Uzamsal olanın uzamsal olmayan tümlüğünü, yani uzamın uzamsallığını düşünme, salt aklın aşkınsal işleyişinin bir ürünüdür, aklın sınırları içinde kalır ve gerçeklikle ilişkilendirilemez (Camcı, 2010, s. 10).

$\mathrm{Bu}$ anlamda evren idesi Kant'ta, Heidegger'in kastettiği dünyasallık anlamında düşünülemez. Heidegger için dünyasallık, varoluşun olanaklarını ve belirlenmişliğin bir aşımını (otantik varoluş, eksistensiyal anlayış anlamında) içerse de, Kant bu aşmayı, belirlenmemişliği, aklın koşulsuz buyruklarında görür. Çünkü insan, nedenselliğin belirlediği ampirik yanından, yine kendi aklında bulunan koşulsuz bir düşünme yetisiyle kurtulur. Bu da aslında, insanın özgürlük olanağını anlatır. Aklın, duyulara dayanmayan, anlama etkinliğini içeren yanı, bir nedensellik dizisinin, belirlenmişliğin dışındadır. O, bir ilk neden gibi, özgür eylemenin olanağıdır. İnsan, doğanın nedenselliğine bağlı olan ampirik yanından, kendi aklının anlamaya, karar vermeye, seçebilmeye dönük ahlaki yanında özgürleşir (Heimsoeth, 2007, ss. 109-112).

\section{Kuramsal Değil, Kuram-Öncesi Karşılaşma, Etkilenme}

Descartes'ın insanı ruhsal ve bedensel bir töz olarak belirleyişi ve bu ayrımı doğaya da uygulayışı; Kant'ın töz anlamında değil ama özne-nesne ayrımında bu düşünmeyi sürdürüşü; hem insanın hem de birlikte-var-olduğu dünyanın sistematik bir yaklaşımla anlaşılmasına neden olmuştur. Burada Heidegger için problem, kuramsal yaklaşımın kendisidir. Çünkü yaşama ilişkin bir kuramsallaştırma, onun canlılığını yitirmesine neden olmakta; insanın kendisine ilişkin bir olay olarak Ereignis $^{6}$ durumundan, bir Vo rgang'a, tasarımsal bir anlayışa (teknik, bilimsel, seyirsel anlamında) indirgenmektedir. Fakat Heidegger'in bu tutumu, pratik olanın kuramsal olana üstünlüğünü savunması gibi anlaşılmamalıdır. Ona göre, kuramsal bilgi tarzı reddedilmelidir, çünkü kuramsal olanın kendisi aslında kuram-öncesi (pre-teorik) bir şeye işaret etmektedir. Dolayısıyla anlayışı kuramdan uzaklaştırmak, aslında dolayımsız bir karşılaşmayı ima eder. Verili ya da belirlenmiş bir şeyle gerçekleşen karşılaşma, gözlemci konumunda bir seyir ya da karşılaşmadan farklıdır. Bu noktada herhangi bir şeyin bize nasıl verildiği, verilmişliğin kendisinin ne olduğu önem kazanır. Genellikle verilmişliği, bir şey vardır derken ifade ederiz. Var olan 1 , yani verili olan 1 belirleyebilsek de, var-dırın yani verilmişliğin anlamının kendisi zaten bize verilidir. Peki, bu anlam nedir ve nasıl verilir? (Polt, 2005, s. 376).

\footnotetext{
6 Dünyanın dünyasallığına ilişkin olarak, insanın, çevreleyen-dünyasındaki el-altında-olan nesnelerle karşılaşmasını anlatan günlük yaşam deneyimleri (Pollt, 2005, s. 379).
} 
Heidegger'in bu soruya verdiği cevap, dünyanın dünyasallı̆̆ıdır. Ona göre, yalnızca dünya dünyalaşabilir, çünkü bir orada olmadan hiçbir şey olamaz. Şeyler, kendilerini orada, bir çevre ya da dünya içinde sunarlar ve bu dünya içerisinde de herhangi bir şey (seiende) değildirler. Dünyanın dünyasallığını oluşturan ve insan ilgileriyle belirlenen bağlamsal bir yapıda, orada yer edinirler (Polt, 2005, s. 376).

Heidegger, dünyasallık (Weltlichkeit) terimini tanımlamak için deneyim anlamına gelen Erlebnis terimini kullanır. Aynı zamanda bu terim; leben, yaşamak terimiyle de ilişkilidir. Dolayısıyla Erlebnis, insanın eylemlerini, geleceğini, başarı ve başarısızlıklarını barındıran, hayatının bir parçasını oluşturan, yaşadığı kendine ait bir deneyimdir. Bu bakımdan yaşam, düzenli bir işleyiş ya da organizma değil, bir biyoloji de değil, ama biyografideki bir bilmece, sır (bios) gibidir. Bana ait deneyimlerimden oluşan yaşamım, bilimsel bir belirleyiş içinde anlaşılamaz. O ancak, var-olarak deneyimlediğim bir sırrın açılışıdır. Günlük olağan deneyimlerimde kendi kendime bir yerde, orada ikamet edişimde, her ne zaman olursa olsun benim için dünyalaşan bir dünyadayımdır. Kendi amaçlarımla ya da yetilerimle katıldığım, somut ve tarihsel beni oluşturduğum, belirli bir kültürel yapıda yaşarım. Dünya, benim için tüm verili şeyleri içeren ve bu şeylerle günlük deneyimlerimde meşgul olduğum bağlamsal bir yapıdır. Bu noktada Heidegger'e göre, yaşam deneyimimin bana ait olması, gerçekliği öznelliğe indirgeyen bir yaklaşım olarak düşünülmemelidir. Deneyimim, benim soyutlanmış zihnimde, hiçbir şekilde açıklanamayacak ruhsal bir süreçte değil, içinde bulunduğum, ikamet ettiğim, ilgi ve yönelim içinde olduğum ilişkisel ve bütünsel bir yapıda, orada-lıkta gerçeklik kazanır. Bu bakımdan Heidegger'e göre, modern felsefenin bu tarz problemler yaratmasının sebebi, dünya fenomenini görememiş olmasıdır. Özne-nesne ayrımının peşinde, bir şey olmayan dünya unutulmuştur (Polt, 2005, s. 377).

\section{Sonuç}

Descartes'ın cogito'sunun ve Kant'ın aşkınsal beninin getirdiği bakış açısı, insanı, dış dünyayı ve aslında varlığı, düşünsel ve uzamsal gibi ayrımlar temelinde anlamaya neden olmuştur. Varlık Descartes için düşünen ben, uzamsal beden ve dış dünya olarak tözsel bir yapıdadır. Tüm varoluş, cogitonun idesel bilişiyle kesinlik ve gerçeklik kazanır. Kant da benzer şekilde, varlığ 1 aşkınsal ben'in işlevselliğinde anlar. Kesin ve güvenilir olarak tüm varoluşu sağlayan bilmektir, yani varlığı algı ve apriori formlarımız sayesinde anlaşılabilir, apriori sentetik yargılar olarak ifade edebilmektir.

Heidegger için insanı ve dünyayı bu şekilde anlamak, onları asıl varoluşlarından uzaklaştırmaktır. İnsan, kendisi için yapılan tüm ayrımlardan önce çalışan, eylem halinde, iş gören bir var olandır. $\mathrm{Bu}$ davranışı, onun günlük yaşamındaki ilgileri, uğraşları için yönelişinin bir sonucudur. Yönelimsel bir var olan olarak her günkü dünyasında düşünmeden, beklemeden, seyirci olmadan katılır, meşgul olur. Kant'ta, Descartes'ta ya da geleneksel ontolojide olduğu gibi ayrıca kurgusal, bilimsel bir düşünme içinde değildir. Düşünmesi ve anlayışı her zamanki eylemlerinde farkında olmadan ona eşlik eder. Yürürken, arabaya 
binerken, yemek hazırlarken, çalışırken, okurken, her zaman aynı zamanda anlar. Farkında olmadan ilişkilerde bulunur, bağlamsallıklar yaratır ve kendi yaşam dünyasını oluşturur. İnsan, Dasein olarak, kendisine orada bir yer edinir, anlam dünyası açar. Dolayısıyla tüm deneyimlerinde dünyayı bilen bir özne değil, dünya-ile-birlikte-var-olan bir bütündür. Uzama ilişkin varoluşunda geliştirdiği anlayışla, uzamsallığ yani dünyasallığı oluşturan ve bunu her seferinde yeniden deneyimleyerek verilmişliği ve sürekliliği sağlayan bir var olandır. Bu anlamda Heidegger için dünyanın dünyasallığı, onun yaşam ve anlam dünyası, yani varoluşu demektir. Var olanın varlığının anlamı da, var olmaya üstün bir kuramsallaştırma ile değil, var-olmakla anlaşılabilir. 


Kaynakça
Camc1, C. (2014). Heidegger'de Zaman Kavramının Varlıkla Ilişsisi. Antalya:

Yayımlanmamış Kitap.

(2010). Aydınlanmanın Kurgusal Olanağı Olarak Özgürlük Etik İlişkisi. İsmail Serin (Ed.), Birinci Uluslararası Felsefe Kongresi/Eşitlik, Özgürlük, Kardeşlik (s. 789-806). Bursa: Asa. http://philosophy.uludag.edu.tr/ufk/sites/default/files/978-975-8149-42-1.pdf Cassirer, E. (1996). Kant’ın Yaşamı ve Öğretisi. Doğan Özlem (Çev.). İstanbul: İnkılâp.

Descartes, R. (1998). Anlığın Yönetimi İçin Kurallar ve İlk Felsefe Üzerine Meditasyonlar. Aziz Yardımlı (Çev.). İstanbul: İdea -Guignon, C. B. (1983). Heidegger and the Problem of Knowledge. Indiana (USA): Hackett Heidegger, M. (2008). Varlık ve Zaman. Kaan H. Ökten (Çev.). İstanbul: Agora. Heimsoeth, H. (2007). Kant’ın Felsefesi. Takiyettin Mengüşoğlu (Çev.). Ankara: Doğu Batı. Polt, R. (2005). Ereignis. Hubert L. Dreyfus, \& Mark A. Wrathall (Ed.), A Companion To Heidegger (ss. 375-391). USA: Blackwell.

Tümkaya, B. (2010). Heidegger'in Batı Metafiziğine Yönelik Tedirginliği ve Modern Özne Eleştirisi. (Yayımlanmamış yüksek lisans tezi). Akdeniz Üniversitesi/Sosyal Bilimler Enstitüsü, Antalya.

Uzun, E., Güçlü, B., Uzun, S., \& Yolsal, Ü. H. (2003). Felsefe Sözlüğü. Ankara: Bilim ve Sanat.

Yalçın, Ş. (2010). Modern Felsefede Benlik. İstanbul: Boğaziçi Üniversitesi 